\title{
Effect of Vitamin D supplementation on Insulin Resistance in Vitamin D-Deficient Obese Saudi Females; Randomized Controlled Trial
}

\author{
Noura S. Al-Mulhim, MS, Rabia Latif, PhD, Lubna I. Al-Asoom, PhD, \\ Ahmed A. Al-Sunni, PhD, and Tharwat G. Eldin, PhD
}

Department of Physiology, College of Medicine

University of Dammam, Dammam, Saudi Arabia

\author{
Correspondence \\ Dr. Rabia Latif \\ Department of Physiology, College of Medicine \\ University of Dammam \\ P.O. Box 1982 \\ Dammam 31411, Saudi Arabia \\ e-M: rlhussain@uod.edu.sa
}

Submission: 22 October 2014

Accepted: 23 December 2014

\section{Citation}

Al-Mulhim NS, Latif R, Al-Asoom LI, Al-Sunni AA, Eldin TG. Effect of vitamin D supplementation on insulin resistance in vitamin D-deficient obese Saudi females; randomized controlled trial. JKAU Med Sci 2015; 22(1): 25-31.

\begin{abstract}
This study evaluates the effects of vitamin $D$ supplementation on insulin resistance in vitamin D deficient obese Saudi females. Thirty vitamin $D$ deficient obese female students were recruited from University of Dammam, Saudi Arabia and divided into a vitamin D group and a placebo group. Homeostasis model assessment of insulin resistance was compared between the groups and within the groups by two samplettestand paired t test, respectively. After treatment with $50,000 \mathrm{IU}$ of vitamin D weekly for 8 weeks, the mean plasma levels of 25-hydroxy-vitamin D was significantly increased from 2.9 to $31.3 \mathrm{ng} /$ $\mathrm{ml}$ in the vitamin D group. The results in the vitamin D supplemented group at baseline and at the end, for fasting plasma glucose were 97.90 \pm 2.13 and $101.01 \pm 1.67 \mathrm{mg} / \mathrm{dl}(P=0.21)$, for insulin, $5.14 \pm 3.22$ and $4.68 \pm 3.24 \mu \mathrm{lU} / \mathrm{ml}(\mathrm{P}=0.15)$ and for Homeostasis model assessment of insulin resistance, $1.28 \pm 0.81$ and $1.23 \pm 0.87(P=0.62)$, respectively. This data showed insignificant changes in insulin resistance after treatment with vitamin $D$, suggesting that vitamin $D$ supplementation may not have any effect on insulin resistance in vitamin $D$ deficient obese females.
\end{abstract}

\section{Keywords}

Insulin resistance, Obesity, Vitamin D, Randomized controlled trial.

\section{Introduction}

Type 2 diabetes mellitus accounts for approximately $90 \%-95 \%$ of all diabetes cases and has become increasingly prevalent worldwide. It is considered an "Epidemic of the 21st Century", affecting approximately 382 million individuals worldwide and 3.5 million individuals in Saudi Arabia in 2013 ${ }^{[1]}$. Recent evidence suggests that altered vitamin $\mathrm{D}(\mathrm{VD})$ homeostasis may play a role in the development of type 2 diabetes. Type
2 diabetes is characterized by impaired pancreatic $\beta$ cell function and insulin resistance. Animal studies show that VD may influence both of these processes. In in vitro and in vivo studies, glucose-mediated insulin secretion was impaired in VD deficient subjects ${ }^{[2-5]}$, whereas VD supplementation restored the insulin secretion ${ }^{[2,4-7]}$. The active form 1,25 dihydroxy vitamin $D$ binds to the VD receptor, which is expressed in pancreatic $\beta$ cells $s^{[8,9]}$. The existence of the vitamin $D$ response element in the human insulin gene promoter ${ }^{[10]}$ and transcriptional 
activation of the human insulin gene caused by 1,25 dihydroxy vitamin $\mathrm{D}^{[11]}$ further supported a direct effect of VD on insulin synthesis and secretion. Vitamin D has a direct effect on insulin sensitivity by stimulating the expression of insulin receptors in both muscle and adipose tissues ${ }^{[12]}$. In addition, VD has anti-inflammatory and immuno-modulating effects, and might cause a decrease in insulin resistance and an increase in insulin secretion by modulating the immune system ${ }^{[13,14]}$.

There is substantial evidence of alterations in the VD-endocrine system in obese subjects ${ }^{[15]}$. Low levels of VD are common in association with obesity ${ }^{[16,17]}$. Total body fat is inversely related to VD levels in women even after adjustment for age, lifestyle, and Parathyroid Hormone (PTH) ${ }^{[18]}$. VD is stored in adipose tissue (AT), and released later on during the winter, when cutaneous production is low or absent ${ }^{[19]}$. Suggested mechanisms underpinning the low levels of VD in obesity include; a decreased exposure to sun light ${ }^{[20]}$, or a decreased hepatic activation of VD in obesity inhibited by elevated levels of 1,25-dihydroxy VD and PTH ${ }^{[21]}$. The expression levels of VD-metabolizing enzymes have been shown to decrease in the adipose tissue of obese subjects ${ }^{[22]}$, signifying that the ability of adipose tissue to metabolize VD can be dynamically altered during obesity and weight loss.

The above mentioned facts suggest a close relationship between plasma levels of VD, Obesity and Insulin resistance. Several VD-interventional trials have been conducted worldwide to explore the link among these three parameters; however the data from these trials are inconsistent and lack conclusive evidence ${ }^{[23-29]}$. Moreover, none of the Vitamin D intervention studies have been conducted in KSA; a country where prevalence of VD deficiency in females has been found to be $99 \%{ }^{[30]}$. Low levels of VD are more common in Saudi females and in the younger age groups; most likely due to the wearing of traditional clothes, limited exposure to sun, and inadequate dietary intake. The current study; first VD intervention trial in KSA; aimed to investigate the effects of oral vitamin D supplementation on glucose homeostasis in Vitamin D deficient Saudi obese adolescent females.

\section{Materials and Methods}

Approval of this randomized, placebo controlled study was granted by Research and Ethics Committee of University of Dammam. All Saudi females studying at health colleges in the university $(\mathrm{N}=698)$ were assessed for eligibility criteria. The inclusion criteria were 18-23 years old, obese $\left(B M I>30 \mathrm{~kg} / \mathrm{m}^{2}\right)$, VD deficient (serum 25 $(\mathrm{OH}) \mathrm{VD}<20 \mathrm{ng} / \mathrm{ml}\left(<50 \mathrm{nmol} / \mathrm{L}^{[24]}\right.$ Saudi females willing to participate. Students with any history of systemic illness, regularly taking multivitamins especially VD, pregnancy or lactation were excluded from the study. Out of 44 students meeting the inclusion criteria, 10 students withdrew consent for personal reasons and 4 students were excluded due to recent major weight loss.

Study participants were randomly assigned into VD group (received 50,000 IU/wk of vitamin D3 drops) or placebo group (received normal saline drops/wk) for 8 weeks duration. A block randomization procedure with serial entry in blocks was used ${ }^{[28]}$. Four participants were included in each block, ensuring that within each block two participants were allocated to VD group and two were allocated to placebo group. All participants from both groups received their dose under supervision in the Physiology Department Laboratory, College of Medicine, University of Dammam. Participants were advised to maintain their usual diets and avoid taking VD supplementation on their own throughout the study period.

VD status was assessed before randomization to involve only VD deficient subjects. VD level was measured by serum $25(\mathrm{OH})$ ELISA instead of gold standard methods; high performance liquid chromatography (HPLC) and Liquid Chromatography: Tandem Mass Spectrometry Method (LC-TM) because ELISA is relatively cheap and has sensitivity comparable to HPLC and LC-TM ${ }^{[31]}$. Fasting blood samples were obtained at the baseline and at the end of 8-weeks supplementation period and then centrifuged to separate the serum.

Fasting glucose was automatically measured by using glucometer (ACC-Chek G, Roche Diagnostics $\mathrm{GmbH}$, Mannheim, Germany) which has been reported to perform well and give accurate results ${ }^{[32,33]}$. Since whole blood glucose values are typically lower than the plasma values, those were subsequently converted to equivalent plasma glucose, after multiplication with a constant factor $1.11^{[34]}$.

Serum insulin was measured by insulin (human) ELISA kit ${ }^{[28]}$. (Phoenix Pharmaceuticals Inc., Mannheim, Germany) (Cat. No. EK-035-06) with intra- and inter-assay variations $<10 \%$ and $<15 \%$, respectively.

Insulin sensitivity was estimated by homeostasis model assessment of insulin resistance (HOMA-IR) using the following formula ${ }^{[35]}$.

\section{HOMA-IR = Fasting Plasma Glucose $\mathrm{x}$ Fasting Insulin/405}

Fasting insulin and fasting glucose were measured in $(\mu \mathrm{lU} / \mathrm{ml})$ and $(\mathrm{mg} / \mathrm{dl})^{[36]}$.

HOMA-IR is the most frequently employed simple technique both in clinical practice and in epidemiological studies. HOMA-IR has a high correlation with measures of insulin sensitivity obtained from the euglycemic clamp procedure ${ }^{[35]}$. High HOMA-IR scores denote low insulin sensitivity (increased insulin resistance). 


\section{Statistical Analysis}

The data were analyzed using Microsoft Excel (Microsoft Inc., Redmond, WA USA) version 2010 and the Statistical Package of Social Science (IBM SPSS Statistics, Armonk, New York, USA) version 20. Data are presented as means \pm Standard Error of Mean (SEM). Differences between groups were assessed by a two-sample $t$ test. Paired sample $t$ test was used to compare changes within each group (pre- and post-treatment) of all variables. A ' $p$ ' value of $<0.05$ was taken as statistically significant.

\section{Results}

The baseline characteristics of all participants are represented in Table 1 and Figure 1. There were no significant differences in age (20.26 years vs. 19.67; $P$ $=0.25$ ), Body Mass Index (32.19 vs. $34.53 ; \mathrm{P}=0.09$ ) or plasma 25-hydroxy-vitamin $\mathrm{D}(25(\mathrm{OH}) \mathrm{D})(3.089 \pm 1.06$ $\mathrm{ng} / \mathrm{ml}$ vs. $2.9 \pm 0.93 ; \mathrm{P}=0.7$ ) between groups at baseline. After treatment with 50,000 IU of cholecalciferol weekly for 8 weeks, the mean plasma levels of $25(\mathrm{OH}) \mathrm{D}$ was significantly increased from 2.9 to $31.3 \pm 9.2 \mathrm{ng} / \mathrm{ml}$ in vitamin $\mathrm{D}$ group (Table 2). Fasting plasma glucose significantly decreased in Vitamin D group compared with placebo (two-sample $t$ test) and within the placebo group (paired $t$ test). Comparison within groups as done by paired $t$ test revealed statistically insignificant differences in HOMA-IR in both groups (Table 3).

Table 1. Baseline characteristics of study participants.

\begin{tabular}{|l|c|c|c|}
\hline & Placebo & Vitamin D & \multirow{2}{*}{ P Value } \\
\hline & (Mean \pm SEM) & (Mean \pm SEM) & \\
\hline 25(OH)D $(\mathrm{ng} / \mathrm{ml})$ & $3.089 \pm 1.06$ & $2.9 \pm 0.93$ & 0.7 \\
\hline FPG $(\mathrm{mg} / \mathrm{dl})$ & $94.79 \pm 2.52$ & $97.90 \pm 2.13$ & 0.354 \\
\hline Insulin $(\mu \mathrm{lU} / \mathrm{mL})$ & $6.25 \pm 3.29$ & $5.14 \pm 3.22$ & 0.811 \\
\hline HOMA-IR & $1.32 \pm 0.65$ & $1.28 \pm 0.81$ & 0.967 \\
\hline
\end{tabular}

${ }^{*}$ Differences between groups were compared using a two samplet test at $P<0.05$. 25(OH)D: 25-hydroxy-vitamin D; FPG: fasting plasma glucose;

HOMA-IR: Homeostasis model assessment of insulin resistance.

Table 2. Post-treatment characteristics of study participants.

\begin{tabular}{|l|c|c|c|}
\hline & Placebo & Vitamin D & P-Value \\
\hline 25(OH)D (ng/ml) & $5.7 \pm 1.6$ & $31.3 \pm 9.2$ & $<0.0001^{\dagger}$ \\
\hline FPG $(\mathrm{mg} / \mathrm{dl})$ & $106.56 \pm 1.49$ & $101.01 \pm 1.67$ & $0.020^{*}$ \\
\hline Insulin $(\mu \mathrm{lU} / \mathrm{mL})$ & $6.28 \pm 3.22$ & $4.68 \pm 3.24$ & 0.728 \\
\hline HOMA-IR & $1.73 \pm 0.90$ & $1.23 \pm 0.87$ & 0.694 \\
\hline
\end{tabular}

Differences between groups were compared using a two samplet test at $P<0.05$.

${ }^{*} P<0.05 ; \uparrow P<0.001$

25(OH)D: 25-hydroxy-vitamin D; FPG: fasting blood glucose;

HOMA-IR: Homeostasis model assessment of insulin resistance.

Table 3. Comparison of Pre and Post-treatment values in vitamin D and placebo groups.

\begin{tabular}{|l|c|c|c|c|c|c|}
\hline \multirow{2}{*}{} & \multicolumn{3}{|c|}{ Groups } \\
\cline { 2 - 7 } & \multicolumn{3}{|c|}{ Placebo } & Pitamin D \\
\cline { 2 - 7 } & Pre Test & Post Test & P-values & Pre Test & Post Test & P-values \\
\hline $25-$ OHD $(\mathrm{ng} / \mathrm{ml})$ & $3.089 \pm 1.06$ & $5.52 \pm 1.71$ & 0.001 & $2.9 \pm 0.9$ & $31.3 \pm 9.2$ & $<0.0001^{*}$ \\
\hline FPG $(\mathrm{mg} / \mathrm{dl})$ & $94.79 \pm 2.52$ & $106.56 \pm 1.49$ & $0.01^{*}$ & $97.90 \pm 2.13$ & $101.01 \pm 1.67$ & 0.21 \\
\hline Insulin $(\mu \mathrm{ll} / \mathrm{mL})$ & $6.25 \pm 3.29$ & $6.28 \pm 3.22$ & 0.96 & $5.14 \pm 3.22$ & $4.68 \pm 3.24$ & 0.15 \\
\hline HOMA-IR & $1.32 \pm 0.65$ & $1.73 \pm 0.90$ & 0.22 & $1.28 \pm 0.81$ & $1.23 \pm 0.87$ & 0.62 \\
\hline
\end{tabular}

Values are reported as Mean \pm SEM. Comparison within groups was done by paired t test.

${ }^{*} P<0.001$

25(OH)D: 25-hydroxy-vitamin D; FPG: fasting plasma glucose; HOMA-IR: Homeostasis model assessment of insulin resistance

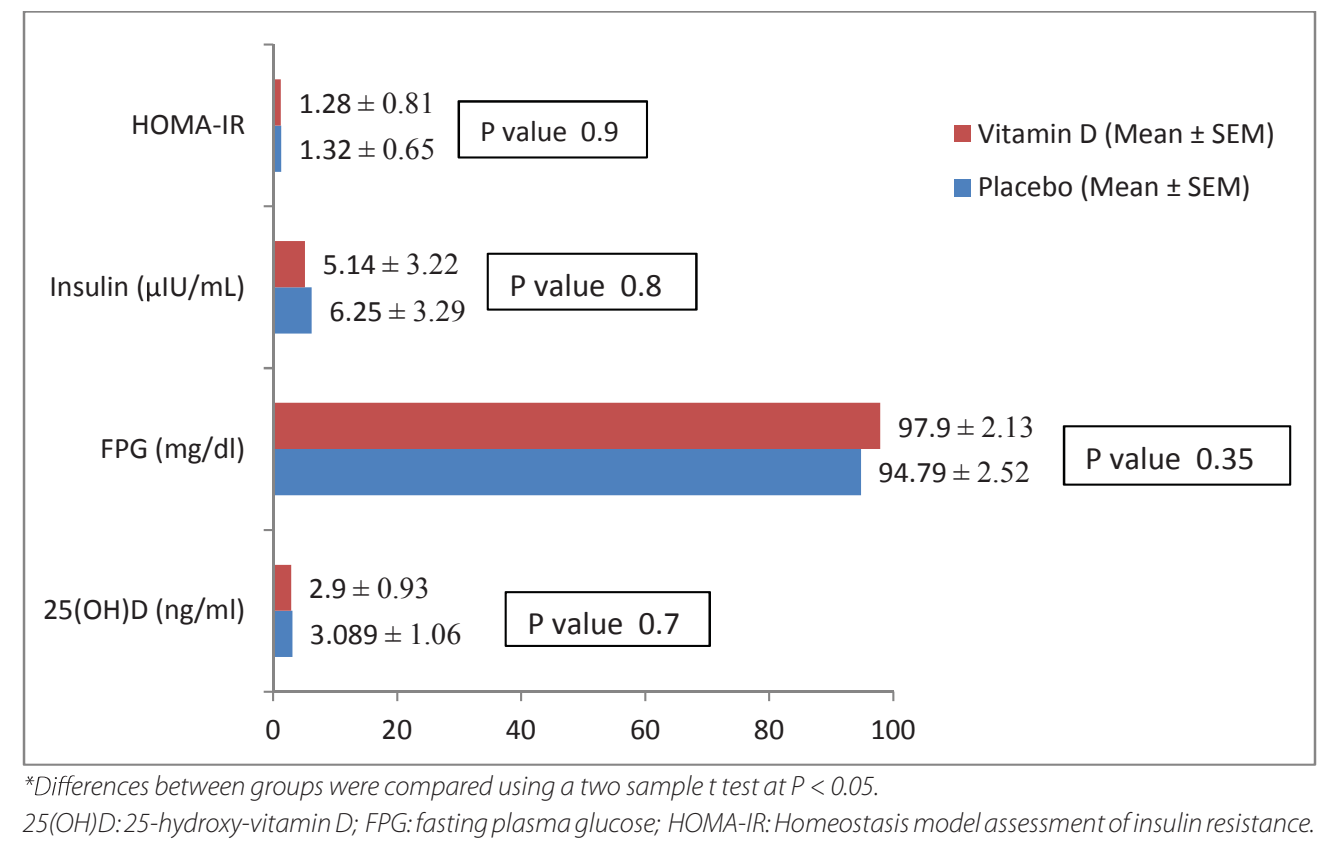

Figure 1. Baseline characteristics of study participants. 


\section{Discussion}

Out of 698 students screened, only $6.59 \%$ were found to be obese. This prevalence of obesity is much less than the prevalence reported in previous studies. In a community-based national epidemiological health survey conducted in 2005 , the prevalence of obesity was found to be $35.5 \%{ }^{[37]}$. Another survey involving only the eastern province found the overall prevalence of obesity to be $43.8 \%{ }^{[38]}$. The reason for low obesity prevalence in these study subjects could be that these students at health colleges were more educated about the health issues relating to weight and so were actively managing their weight.

Prevalence of VD deficiency found in these subjects was $94 \%$. It is in accordance with previous studies. Al $\mathrm{Erq}^{[30]}$ found VD deficiency prevalence to be $99 \%$ in female medical students in Eastern province of KSA. Alfawaz ${ }^{[39]}$ stated the over-all prevalence of vitamin $\mathrm{D}$ deficiency as $78.1 \%$ in Saudi females; significantly associated with increasing weight. Ardawi et al., ${ }^{[40]}$ reported prevalence to be $80 \%$ in Saudi females; largely attributed to obesity and poor exposure to sunlight due to their traditional clothing.

In the present study vitamin D3 treatment $(50,000$ IU/Wk) for 8 weeks led to increased mean plasma levels of 25(OH)D from deficient levels $(<20 \mathrm{ng} / \mathrm{ml})$ to sufficient levels ( $>30 \mathrm{ng} / \mathrm{ml}$ ) and this finding seems to be consistent with a previous study which found that high doses of cholecalciferol supplementation for 8 weeks would be enough to increase the mean plasma levels of 25(OH)D to sufficient range ${ }^{[4] 1}$.

The significant difference between placebo and vitamin D- treated groups in plasma glucose levels was probably due to significantly increased glucose in placebo group (pre vs. post). The reason for this is not clear but it may be due to the effect of exam stress which led to excess secretion of cortisol and catecholamines since the blood collection from both groups was just before the exams. Lack of significant increase in blood sugar in vitamin $D$ supplemented group might be because of cortisol-antagonizing effects of vitamin $D$ which needs further exploration.

This study did not show any significant improvement in insulin sensitivity after high dose of VD supplementation for 8 weeks. This finding is in agreement with Pittas et al. (2007) ${ }^{[42]}$ who showed no significant difference in a 3 year clinical trial in insulin sensitivity between placebo and VD groups in subjects with normal fasting glucose. Also, the present finding seems to be consistent with that of Nagpal et al. ${ }^{[23]}$ who found that short term oral supplementation with VD for 6 weeks in healthy, centrally obese men had no effect on HOMA-IR. Recently in a double blind, placebo controlled randomized clinical trial, Wamberg et al., ${ }^{[28]}$ showed lack of effect of 26 weeks vitamin D supplementation on insulin resistance in vitamin $\mathrm{D}$ deficient obese (BMI > $30 \mathrm{~kg} / \mathrm{m}^{2}$ ) adults. In another double-blind, randomized, control study ${ }^{[26]}$ with prediabetic subjects; a high dosage of vitamin D supplementation (88,865 IU/week) for 1 year had no effect on insulin sensitivity. Interventional trials using vitamin $D$ supplementation in subjects with existing type 2 diabetes have also shown no overall improvement in insulin resistance ${ }^{[43-45]}$. Similarly, two other randomized trials conducted on obese adults showed that VD supplementation had no effects on glycemia, insulin resistance, and insulin secretion ${ }^{[27,28]}$.

On the other hand, few studies have shown an increase in insulin sensitivity after VD supplementation. Nazarian etal., ${ }^{[46]}$ showed that insulin sensitivity improved in subjects with VD supplementation compared with placebo. In contrast to this study, they used an aggressive VD replacement regimen (10,000 IU/day vs. 50,000 IU/ week), and their subjects were having impaired fasting glucose vice normal fasting glucose. Similarly von Hurst et al., ${ }^{[47]}$ showed that administration of 4000 IUVD daily for 6 months to insulin resistant South Asian women, aged 23-68 years resulted in attenuation of insulin resistance. Their VD administration protocol (daily dosage, longer study duration) is different from this study's (weekly doses, shorter study duration). While the less frequent doses may be beneficial from a compliance viewpoint; daily doses have been shown to be more effective than weekly or monthly doses as measured by serum $25(\mathrm{OH})$ $D^{[48]}$. It seems that this study's intervention did not raise VD concentration to a level at which insulin resistance is attenuated. Moreover, subjects participating in von Hurst et al. research ${ }^{[47]}$ were insulin resistant in contrast to this study's subjects who were not insulin resistant (in obese adolescents, HOMA-IR values greater than 3.2 are considered insulin resistant) ${ }^{[49]}$. There is a possibility that VD supplementation may affect insulin sensitivity differently in those with impaired insulin resistance.

\section{Conclusion}

Correction of VD deficiency seems to have insignificant effects on blood glucose levels, insulin concentration, and insulin sensitivity in young obese female subjects with normal baseline insulin resistance index HOMA-IR.

\section{Limitations}

The limitations of this study include the small sample size and the short duration of the study.

\section{Acknowledgment}

The authors acknowledge the financial support from Deanship of Scientific Research, University of Dammam, Saudi Arabia by grant number P2012011. 


\section{Vitamin D, Insulin Resistance, Obesity, Randomized Controlled Trial N.S. Al-Mulhim et al.}

\section{References}

[1] International Diabetes Federation. IDF Diabetes Atlas, $6^{\text {th }}$ ed. Brussels, Belgium: International Diabetes Federation, 2013. $<$ http://www.idf.org/diabetesatlas $>$.

[2] Norman AW, Frankel JB, Heldt AM, Grodsky GM. Vitamin D deficiency inhibits pancreatic secretion of insulin. Science 1980; 209(4458): 823-825.

[3] Kadowaki S, Norman AW. Dietary vitamin D is essential for normal insulin secretion from the perfused rat pancreas. J Clin Invest 1984; 73(3): 759-766.

[4] Tanaka $Y$, Seino $Y$, Ishida M, Yamaoka K, Yabuuchi H, Ishida $H$, Seino S, Seino $Y$, Imura $H$. Effect of vitamin D3 on the pancreatic secretion of insulin and somatostatin. Acta Endocrinol (Copenh) 1984; 105(4): 528-533.

[5] Cade C, Norman AW. Vitamin D3 improves impaired glucose tolerance and insulin secretion in the vitamin D-deficient rat in vivo. Endocrinology 1986; 119(1): 84-90.

[6] Bourlon PM, Faure-Dussert A, Billaudel B. The de novo synthesis of numerous proteins is decreased during vitamin D3 deficiency and is gradually restored by 1 , 25-dihydroxyvitamin D3 repletion in the islets of Langerhans of rats. J Endocrinol 1999; 162(1): 101-109.

[7] Clark SA, Stumpf WE, Sar M. Effect of 1,25dihydroxyvitamin D3 on insulin secretion. Diabetes 1981; 30(5): 382-386.

[8] Johnson JA, Grande JP, Roche PC, Kumar R. Immunohistochemical localization of the 1,25(OH)2D3 receptor and calbindin D28k in human and rat pancreas. Am J Physiol 1994; 267(3 pt 1): E356-E360.

[9] Zeitz U, Weber K, Soegiarto DW, Wolf E, Balling R, Erben RG. Impaired insulin secretory capacity in mice lacking a functional vitamin D receptor. FASEB J 2003; 17(3): 509-511.

[10] Maestro B, Davila N, Carranza MC, Calle C. Identification of a Vitamin $D$ response element in the human insulin receptor gene promoter. J Steroid Biochem Mol Biol 2003; 84(2-3): 223-230.

[11] Maestro B, Molero S, Bajo S, Davila N, Calle C. Transcriptional activation of the human insulin receptor gene by 1,25-dihydroxyvitamin D(3). Cell Biochem Funct 2002; 20(3): 227-232.

[12] Maestro B, Campión J, Dávila N, Calle C. Stimulation by 1,25-dihydroxyvitamin D3 of insulin receptor expression and insulin responsiveness for glucose transport in U-937 human promonocytic cells. Endocr J. 2000; 47(4): 383-391.

[13] Boucher BJ. Vitamin D insufficiency and diabetes risks. Curr Drug Targets 2011; 12 (1): 61-87.

[14] Alvarez J, Ashraf A. Role of vitamin D in insulin secretion and insulin sensitivity for glucose homeostasis. Int J Endocrinol 2010; 2010: 351385.

[15] Bell NH, Epstein S, Greene A, Shary J, Oexmann MJ, Shaw S. Evidence for alteration of the vitamin D-endocrine system in obese subjects. J Clin Invest 1985; 76(1): 370-373.

[16] Robinson C, Chiang M, Thompson SN, Sondike SB. Occurrence of vitamin D deficiency in pediatric patients at high risk in West Virginia. South Med J 2012; 105(10): 504507.
[17] Lee SH, Kim SM, Park HS, Choi KM, Cho GJ, Ko BJ, Kim $\mathrm{JH}$. Serum 25-hydroxyvitamin D levels, obesity and the metabolic syndrome among Korean children. Nutr Metab Cardiovasc Dis 2013; 23(8): 785-791.

[18] Jungert A, Roth HJ, Neuhäuser-Berthold M. Serum 25-hydroxyvitamin $\mathrm{D}_{3}$ and body composition in an elderly cohort from Germany: a cross-sectional study. Nutr Metab (Lond) 2012; 9(1): 42.

[19] Holick MF. The Vitamin D Epidemic and its Health Consequences. J Nutr 2005; 135(11): 2739S-2748S.

[20] Kull M, Kallikorm R, Lember M. Body mass index determines sunbathing habits: implications on vitamin D levels. Intern Med J 2009; 39(4): 256-258.

[21] Bell NH, Epstein S, Greene A, Shary J, Oexmann MJ, Shaw S. Evidence for alteration of the vitamin D-endocrine system in obese subjects. J Clin Invest 1985; 76(1): 370-373.

[22] Wamberg L, Christiansen T, Paulsen SK, Fisker S, Rask P, Rejnmark L, Richelsen B, Pedersen SB. Expression of vitamin D-metabolizing enzymes in human adipose tissue-the effect of obesity and diet-induced weight loss. Int J Obes (Lond) 2013; 37(5): 651-657.

[23] Nagpal J, Pande JN, Bhartia A. A double-blind, randomized, placebo-controlled trial of the short-term effect of vitamin D3 supplementation on insulin sensitivity in apparently healthy, middle-aged, centrally obese men. Diabet Med 2009; 26(1): 19-27.

[24] von Hurst PR, Stonehouse W, Coad J. Vitamin D supplementation reduces insulin resistance in South Asian women living in New Zealand who are insulin resistant and vitamin $\mathrm{D}$ deficient - a randomised, placebo-controlled trial. Brit J Nutr. 2010; 103(4): 549-555.

[25] Mitri J, Dawson-Hughes B, Hu FB, Pittas AG. Effects of vitamin $D$ and calcium supplementation on pancreatic $\beta$ cell function, insulin sensitivity, and glycemia in adults at high risk of diabetes: the Calcium and Vitamin D for Diabetes Mellitus (CaDDM) randomized controlled trial. Am J Clin Nutr 2011; 94(2): 486-494.

[26] Davidson MB, Duran P, Lee ML, Friedman TC. High-dose vitamin $D$ supplementation in people with prediabetes and hypovitaminosis D. Diabetes Care 2013; 36(2): 260-266.

[27] Harris SS, Pittas AG, Palermo NJ. A randomized, placebocontrolled trial of vitamin $D$ supplementation to improve glycaemia in overweight and obese African Americans. Diabetes Obes Metab 2012; 14(9): 789-794.

[28] Wamberg L, Kampmann $U$, Stødkilde-Jørgensen $H$, Rejnmark L, Pedersen SB, Richelsen B. Effects of vitamin D supplementation on body fat accumulation, inflammation, and metabolic risk factors in obese adults with low vitamin D levels - results from a randomized trial. Eur J Intern Med 2013; 24(7): 644-649.

[29] Belenchia AM, Tosh AK, Hillman LS, Peterson CA. Correcting vitamin $D$ insufficiency improves insulin sensitivity in obese adolescents: a randomized controlled trial. Am J Clin Nutr 2013; 97(4): 774-781.

[30] Al Erq AH. The status of vitamin D in medical students in the preclerkship years of a Saudi Medial School. J Family Community Med 2012; 19(2): 100-104. 
[31] Wallace AM, Gibson S, de la Hunty A, Lamberg-Allardt C, Ashwell M. Measurement of 25-hydroxyvitamin D in the clinical laboratory: current procedures, performance characteristics and limitations. Steroids 2010; 75(7): 477-488.

[32] Dhatt GS, Agarwal MM, Othman Y, Nair SC. Performance of the Roche Accu-Chek active glucose meter to screen for gestational diabetes mellitus using fasting capillary blood. Diabetes Technol Ther 2011; 13(12): 1229-1233.

[33] Tack C, Pohlmeier H, Behnke T, Schmid V, Grenningloh M, Forst T, Pfützner A. Accuracy Evaluation of Five Blood Glucose Monitoring Systems Obtained from the Pharmacy: A European Multicenter Study with 453 Subjects. Diabetes Technol Ther 2012; 14(4): 330-337.

[34] D'Orazio P, Burnett RW, Fogh-Andersen N, Jacobs E, Kuwa K, Külpmann WR, Lasse Larsson L, Lewenstam A, Maas AHJ, Mager G, Naskalski JW, Okorodudu AO. Approved IFCC recommendation on reporting results for blood glucose (abbreviated). Clin Chem 2005; 51(9): 1573-1576.

[35] Matthews DR, Hosker JP, Rudenski AS, Naylor BA, Treacher DF, Turner RC. Homeostasis model assessment: insulin resistance and beta-cell function from fasting plasma glucose and insulin concentrations in man. Diabetologia 1985; 28(7): 412-419.

[36] Okita K, Iwahashi H, Kozawa J, Okauchi Y, Funahashi T, Imagawa A, Shimomura I. Homeostasis model assessment of insulin resistance for evaluating insulin sensitivity in patients with type 2 diabetes on insulin therapy. Endocr J 2013; 60(3): 283-290.

[37] Al-Nozha MM, Al-Mazrou YY, Al-Maatouq MA, Arafah MR, Khalil MZ, Khan NB, Al-Marzouki K, Abdullah MA, Al-Khadra AH, Al-Harthi SS, Al-Shahid MS, Al-Mobeireek A, Nouh MS. Obesity in Saudi Arabia. Saudi Med J 2005; 26(5): 824-829.

[38] Al-Baghli NA, Al-ghamdi AJ, Al-Turki KA, El Zubaier AG, AlAmeer MM, Al-Baghli FA. Overweight and obesity in Eastern province of Saudi Arabia. Saudi Med J 2008; 29(9): 13191325.

[39] Alfawaz H, Tamim H, Alharbi S, Aljaser S, Tamimi W. Vitamin D status among patients visiting a tertiary care center in Riyadh, Saudi Arabia: a retrospective review of 3475 cases. BMC Public Health 2014; 14: 159.

[40] Ardawi MS, Qari MH, Rouzi AA, Maimani AA, Raddadi RM. Vitamin D status in relation to obesity, bone mineral density, bone turnover markers and vitamin $D$ receptor genotypes in healthy Saudi pre- and postmenopausal women. Osteoporos Int 2011;22(2): 463-475.

[41] Goswami R, Gupta N, Ray D, Singh N, Tomar N. Pattern of 25-hydroxy vitamin $D$ response at short (2 month) and long (1 year) interval after 8 weeks of oral supplementation with cholecalciferol in Asian Indians with chronic hypovitaminosis D. Brt J Nutr 2008; 100(3): 526-529.

[42] Pittas AG, Harris SS, Stark PC, Dawson-Hughes B. The effects of calcium and vitamin $D$ supplementation on blood glucose and markers of inflammation in non-diabetic adults. Diabetes Care 2007; 30(4): 980-986.

[43] Gedik O, Akalin S. Effects of vitamin D deficiency and repletion on insulin and glucagon secretion in man. Diabetologia 1986; 29(3): 142-145.

[44] Orwoll E, Riddle M, Prince M. Effects of vitamin D on insulin and glucagon secretion in non-insulin- dependent diabetes mellitus. Am J Clin Nutr 1994; 59(5): 1083-1087.
[45] Borissova AM, Tankova T, Kirilov G, Dakovska L, Kovacheva R. The effect of vitamin D3 on insulin secretion and peripheral insulin sensitivity in type 2 diabetic patients. Int J Clin Pract 2003; 57(4): 258-261.

[46] Nazarian S, St Peter JV, Boston RC, Jones SA, Mariash CN. Vitamin D3 supplementation improves insulin sensitivity in subjects with impaired fasting glucose. Transl Res 2011; 158(5): 276-281.

[47] von Hurst PR, Stonehouse W, Coad J. Vitamin D supplementation reduces insulin resistance in South Asian women living in New Zealand who are insulin resistant and vitamin D deficient - a randomised, placebo-controlled trial. Brit J Nutr 2010; 103(4): 549-555.

[48] Chel VG, Ooms ME, Popp-Snijders C, Pavel S, Schothorst AA, Meulemans CC, Lips P. Ultraviolet irradiation corrects vitamin D deficiency and suppresses secondary hyperparathyroidism in the elderly. J Bone Miner Res 1998; 13(8): 1238-1242.

[49] Keskin M, Kurtoglu S, Kendirci M, Atabek ME, Yazici C. Homeostasis model assessment is more reliable than the fasting glucose/insulin ratio and quantitative insulin sensitivity check index for assessing insulin resistance among obese children and adolescents. Pediatrics 2005; 115(4): e500-e503. 


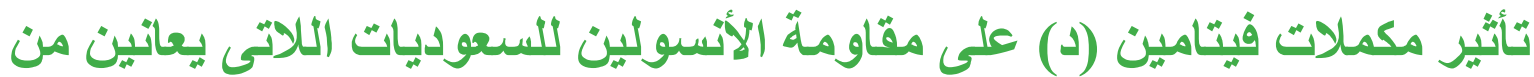

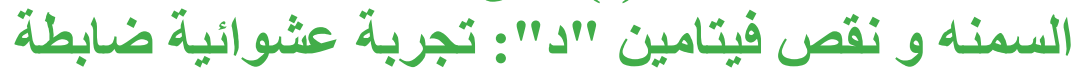

نوره الملحم، ورابية لطيف، ولبنى العسوم، وأحمد السني، وثروت جمال الدين

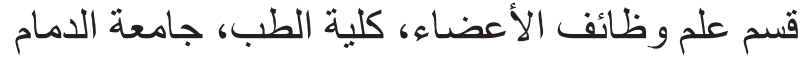

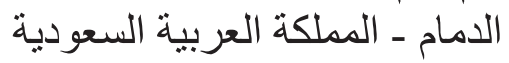

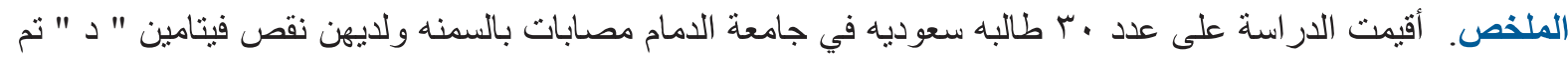

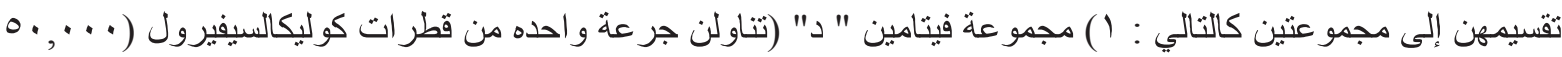

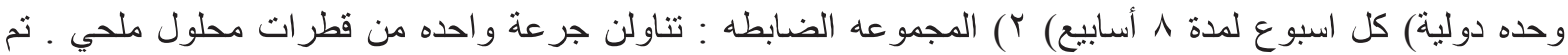

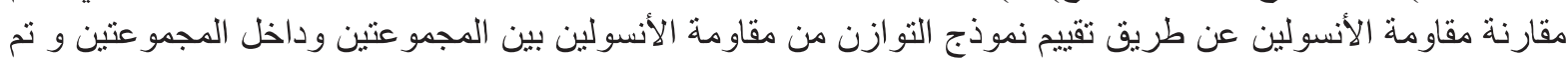

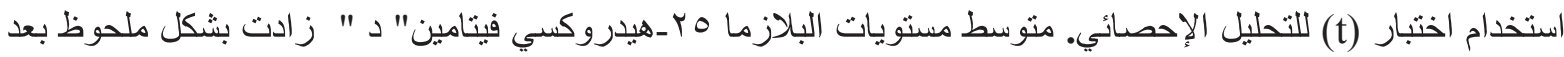

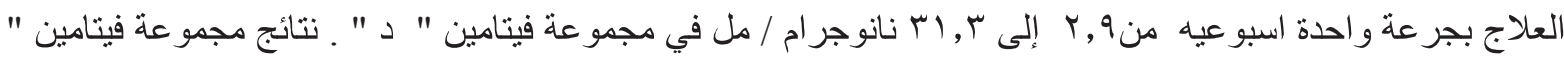

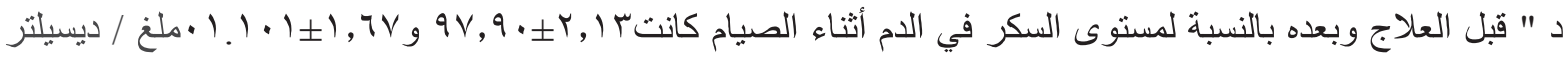

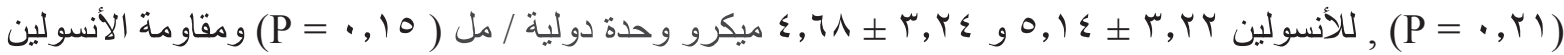

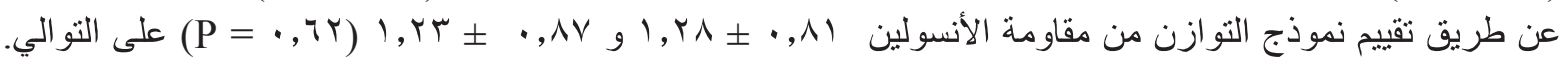
أظهرت نتائج الدراسة تغييرات غير معتبرة إحصائيا بالنسبة لمقاومة الأنسولين بعد العلاج بفيتامين " د " ،, لأى النساء المصابات بالسمنه مع نقص فيتامين " د ". 